\title{
Histone deacetylase inhibitor SAHA attenuates post-seizure hippocampal microglia TLR4/MYD88 signaling and inhibits TLR4 gene expression via histone acetylation
}

\author{
Qing-Peng Hu and Ding-An Mao*
}

\begin{abstract}
Background: Epilepsy is a common neurological disorder characterized by recurrent unprovoked seizures. Seizureinduced TLR4/MYD88 signaling plays a critical role in activating microglia and triggering neuron apoptosis. SAHA is a histone deacetylase inhibitor that regulates gene expression by increasing chromatin histone acetylation. In this study, we investigated the role of SAHA in TLR4/MYD88 signaling in a rat seizure model.

Results: Sprague-Dawley rats with kainic acid (KA)-induced seizures were treated with SAHA. The expression of TLR4, MYD88, NF-KB P65 and IL-1 $\beta$ in hippocampus was detected at hour 2 and 6 and day 1, 2, and 3 post seizure. SAHA pretreatment increased seizure latency and decreased seizure scores. The expression levels of TLR4, MYD88, NF-KB and IL-1 $\beta$ increased significantly in both activated microglia and apoptotic neurons after KA treatment. The effects were attenuated by SAHA. Chromatin immunoprecipitation assays indicated that the $\mathrm{H} 3$ histone acetylation levels significantly decreased while H3K9 levels significantly increased in the KA treatment group. The H3 and H3K9 acetylation levels returned to control levels after SAHA $(50 \mathrm{mg} / \mathrm{kg}$ ) pretreatment. There was a positive correlation between the expression of TLR4 and the acetylation levels of H3K9.
\end{abstract}

Conclusions: Histone deacetylase inhibitor SAHA can suppress seizure-induced TLR4/MYD88 signaling and inhibit TLR4 gene expression through histone acetylation regulation. This suggests that SAHA may protect against seizureinduced brain damage.

Keywords: Histone deacetylase, Seizures, Microglia, Toll-like-receptor 4 (TLR4), MYD88, Histone acetylation, SAHA

\section{Background}

Epilepsy is among the most common brain disorders [1]. Previous studies suggest that inflammation plays an important role in epilepsy development [2-6]. Seizureinduced inflammation can generate a negative feedback loop on neurons [7]. Microglia secretes cytokines (e.g. IL-1 $\beta$ and TNF- $\alpha$ ) during CNS pathological processes [8].

Astrocytes and microglia express toll-like-receptor (TLR) family member proteins such as TLR3 and TLR4

${ }^{*}$ Correspondence: ma_jinan@yahoo.com

Department of Pediatrics, The Second Xiang-Ya Hospital, Central South University, 139 Middle Renmin Road, Changsha 410011, Hunan, China
[9-12]. Expressed in microglia [13-15], TLR4 is closely involved in microglia inflammation responses [16]. Thus, inhibiting TLR4-mediated microglia activation in inflammatory responses could have neuroprotective effects. It has been shown that systemic administration of kainic acid (KA) can induce epileptic seizures, which causes neuroinflammation or neuronal cell death in the hippocampus CA1 and CA3 regions in animals [17-20].

Numerous studies have shown the potential of histone deacetylase (HDAC) inhibitors as novel therapeutics for ischemic stroke [21-23], multiple sclerosis [24] and Huntington's disease [25, 26]. Histone acetyltransferases (HATs) and HDACs reportedly determine the posttranslational acetylation status of chromatin [27]. While 
HATs leads to a transcriptionally-active chromatin structure, HDACs deacetylate and suppress transcription [28]. Therefore, HDAC inhibitors usually reactivate silenced genes [27, 28].

TLR4 signaling leads to activation of two major signal transduction pathways: the myeloid differentiation primary response protein 88 (MyD88)-dependent and MyD88-independent pathways [29]. Previous studies have suggested a key role of MyD88-dependent signaling in developing brain injuries $[29,30]$. The role of microglia TLR4/MyD88 signaling in regulating neuronal cell death and release of inflammatory cytokines following KAstimulation is, as yet, largely unknown.

In this study, we for the first time explored the role of SAHA in TLR4/MYD88 signaling and histone acetylation of TLR4 gene in KA-induced seizures.

\section{Methods}

\section{Animals}

Developing male Sprague-Dawley rats (3 weeks old, weighing 60-80 g) were obtained from the Experimental Animal Center of Hunan University of Chinese Medicine (Changsha, Hunan, China). The animals were housed in conventional conditions at $22{ }^{\circ} \mathrm{C}, 50-60 \%$ humidity with alternating $12 \mathrm{~h}$ light $/ 12 \mathrm{~h}$ dark cycles. Rats were allowed free access to food and water.

\section{Seizure induction}

Male Sprague-Dawley rats were used in this study and were randomly divided into four experimental groups: (1) control group (saline); (2) KA group; (3) "KA $+10 \mathrm{mg} /$ kg SAHA"group; and (4) "KA + $50 \mathrm{mg} / \mathrm{kg}$ SAHA" group. Intraperitoneal administration of KA $15 \mathrm{mg} / \mathrm{kg}$ (Sigma, St Louis, MO, USA) was used to induce seizures. Rats were continuously monitored for seizure activity for $4 \mathrm{~h}$ after KA administration. Behavioral seizures were graded on the Racine scale [31]: stage 1, facial clonus; stage 2, head nodding; stage 3 , forelimb clonus; stage 4 , forelimb clonus with rearing; stage 5 , rearing, jumping, and falling. SAHA (10 or $50 \mathrm{mg} / \mathrm{kg}$; Sigma, St Louis, MO, USA) was injected intraperitoneally $30 \mathrm{~min}$ before KA injection. Seizure latency times and seizure scores were analyzed. After behavioral assessments, the rats were sacrificed with an anesthetic ( $1 \%$ barbital sodium, $500 \mathrm{mg} / \mathrm{kg}$ ) at different post-seizure time points (hour 2 and 6 , and day 1,2 , and 3 ). The rats were then perfused transcardially with saline and the hippocampi were immediately dissected. Samples taken from rats sacrificed at the $2 \mathrm{~h}, 6 \mathrm{~h}$, $1 \mathrm{~d}$ and $2 \mathrm{~d}$ post-seizure time points were used for Western Blot, qRT-PCR, and chromatin immunoprecipitation. The samples were preserved at $-70{ }^{\circ} \mathrm{C}$. Post-seizure rats sacrificed at the three-day mark were used to the experiment of immunohistochemistry and TUNEL staining.
Their brains were removed immediately and fixed overnight using cold $4 \%$ paraformaldehyde at $4{ }^{\circ} \mathrm{C}$.

\section{Western blotting}

Harvested hippocampi were washed in ice-cold PBS and lysed for 10 min using an RIPA lysis buffer. Lysates were centrifuged and supernatant collected. The protein concentration in the lysate supernatant was measured with BCA protein assays (Beyotime, Shanghai, China). Western-blot was performed according to standard procedures. Briefly, equal amounts $(30 \mu \mathrm{g})$ of proteins were separated electrophoretically by SDS-PAGE and then transferred to $0.22 \mathrm{~mm}$ polyvinylidene fluoride membrane (PVDF; Millipore, Bedford, MA). The membranes were soaked in $5 \%$ skimmed milk as blocking buffer for $2 \mathrm{~h}$ and then incubated with appropriate primary antibodies including mouse anti-TLR4 antibody (1:1000; Abcam), rabbit anti-MYD88 antibody (1:1000; Cell Signaling, Beverly, MA, USA), rabbit anti-NF-kB P65 antibody (1:2000; Proteintech), rabbit anti-IL-1 $\beta$ antibody (1:500, Proteintech) and mouse anti- $\beta$-actin (1:2000; Abcam), respectively, at $4{ }^{\circ} \mathrm{C}$ overnight. After washing with phosphate-buffered saline containing $0.1 \%$ Tween20 (PBST), the membranes were incubated with $5 \%$ milk containing the corresponding peroxidase-conjugated secondary antibody (1:5000; Santa Cruz Biotechnology, CA, USA) for $1 \mathrm{~h}$ at room temperature. Following three washes in PBST, immunoreactive bands were visualized by enhanced chemiluminescence (ECL) (Santa Cruz, CA, USA). Band pattern was analyzed with Image Quant ${ }^{\mathrm{TM}}$ LAS 4000 (GE Healthcare, Shanghai, China).

\section{Quantitative (q)RT-PCR analysis}

Total RNA was extracted from hippocampal tissues. Reverse transcription (RT) and Real time Quantitative polymerase chain reaction (qRT-PCR) were performed with GoScript ${ }^{\mathrm{TM}}$ Reverse Transcription kit (A5000; Promega, Madison, WI) and GoTaq ${ }^{\circledR}$ qPCR Master Mix kit (A6001; Promega, Madison, WI). qPCR primers were listed in Table 1. The PCR condition was as follows: for TLR4, Denaturation: $95^{\circ} \mathrm{C}, 45 \mathrm{~s}$; Annealing: $56{ }^{\circ} \mathrm{C}, 45 \mathrm{~s}$; Extension: $72{ }^{\circ} \mathrm{C}, 1 \mathrm{~min} ; 30$ cycles; for MYD88, Denaturation: $95^{\circ} \mathrm{C}, 45 \mathrm{~s}$; Annealing: $55^{\circ} \mathrm{C}, 60 \mathrm{~s}$; Extension: $72{ }^{\circ} \mathrm{C}$, 1 min; 30 cycles; for NF-kB P65, Denaturation: $95^{\circ} \mathrm{C}$, $45 \mathrm{~s}$; Annealing: $58{ }^{\circ} \mathrm{C}, 45 \mathrm{~s}$; Extension: $72{ }^{\circ} \mathrm{C}, 1 \mathrm{~min} ; 30$ cycles; for IL-1 $\beta$, Denaturation: $95{ }^{\circ} \mathrm{C}, 45 \mathrm{~s}$; Annealing: $57^{\circ} \mathrm{C}, 45 \mathrm{~s}$; Extension: $72^{\circ} \mathrm{C}, 1 \mathrm{~min} ; 30$ cycles; for $\beta$-actin, Denaturation: $95^{\circ} \mathrm{C}, 30 \mathrm{~s}$; Annealing: $60^{\circ} \mathrm{C}, 30 \mathrm{~s}$; Extension: $72{ }^{\circ} \mathrm{C}, 30 \mathrm{~s} ; 26$ cycles.

\section{Immunohistochemistry: CD68 staining}

Brain tissue was fixed in $4 \%$ paraformaldehyde and embedded in paraffin. Hippocampal tissues were sliced 
Table 1 Nucleotide sequences of primers for real time quantitative polymerase chain reaction

\begin{tabular}{|c|c|c|}
\hline Gene & Forward primer & Reverse primer \\
\hline TLR4 & $\begin{array}{l}\text { 5'-GAGGTTGCTGTTCTTATTC } \\
\text { TGAT-3' }\end{array}$ & $\begin{array}{l}\text { 5'-GAGTGCTGAAAGTCCAGG } \\
\text { TATT-3' }\end{array}$ \\
\hline MYD88 & $\begin{array}{l}\text { 5'-GAAATACATACGCAACCA } \\
\text { GCAGAAA-3' }\end{array}$ & $\begin{array}{l}\text { 5'-CAGATGAAGGCGTCGAAA } \\
\text { AGC-3' }\end{array}$ \\
\hline$N F-k B$ & $\begin{array}{l}5^{\prime}-\text { GACCTGGAGCAAGCCAT } \\
\text { TAGC-3' }\end{array}$ & $\begin{array}{l}\text { 5'CGGACCGCATTCAAGTCA } \\
\text { TAGT-3' }\end{array}$ \\
\hline $\mid L-1 \beta$ & $\begin{array}{l}\text { 5'-GTGGTATTCTCCATGAG } \\
\text { CTTTGTA-3' }\end{array}$ & $\begin{array}{l}\text { 5'-CCATCTTCTTCTTTGGGTAT } \\
\text { TGTT-3 }\end{array}$ \\
\hline$\beta$-actin & $\begin{array}{l}\text { 5'-TGAGACCTTCAACACCCC }^{\text {AG-3' }} \\
\end{array}$ & $\begin{array}{l}5^{\prime} \text {-GCCATCTCTTGCTCGAAGT } \\
\text { C-3' }\end{array}$ \\
\hline
\end{tabular}

into $5-\mu \mathrm{m}$ thick coronal sections in a cryostat. After dewaxing and hydrating, sections were treated with $3 \%$ $\mathrm{H}_{2} \mathrm{O}_{2}$ for $30 \mathrm{~min}$. After three PBS rinses, the sections were blocked using a $0.5 \%$ bovine serum for $1 \mathrm{~h}$ at room temperature. The sections were then incubated overnight at $4{ }^{\circ} \mathrm{C}$ with mouse polyclonal anti-CD68 antibody (1:100; AbD Serotec, Kidlington, UK) [32]. Sections were then incubated with a goat anti-mouse secondary antibody for $2 \mathrm{~h}$ followed by horseradish peroxidase (HRP)Streptavidin for $1 \mathrm{~h}$ at $37{ }^{\circ} \mathrm{C}$. After three PBS rinses, sections were reacted with a $0.025 \% 3,3^{\prime}$-diaminobenzidine tetrahydrochloride (DAB) solution for $5 \mathrm{~min}$. Finally, sections were mounted onto gelatin-coated glass slides and air-dried. We examined the slides with a Moticam Pro microscope (Moticam, Xiamen, China). ImagePro Plus 6.0 software (Media Cybernetics, Bethesda, MD, USA) was used to calculate the CD68 stained area. The average optical density (mean density) represented the intensity of CD68 expression and was counted in four random fields in the hippocampal CA1 region per section.

\section{TUNEL staining}

TUNEL staining was performed using situ apoptosis detection kit (Millipore, Billerica, MA, USA). Tissue sections were treated with $3 \%$ hydrogen peroxide to quench endogenous peroxidase activity. After adding a labeling buffer, sections were treated with terminal deoxynucleotidyl transferase (TdT) and digoxigenin dUTP for $2 \mathrm{~h}$ at $37{ }^{\circ} \mathrm{C}$. Specimens were then treated with peroxidase-coupled anti-digoxigenin for $30 \mathrm{~min}$ at $37^{\circ} \mathrm{C}$. 3,3'-diaminobenzidine (DAB) was used to detect developing signals. Sections were counterstained with methyl green, rinsed, dehydrated, and mounted. The slides were examined by Moticam Pro microscope (Moticam, Xiamen, China). Each slice was observed using a high-power microscope on three visual fields of the hippocampus, and TUNEL positive cells were counted in each group.

\section{Chromatin immunoprecipitation (ChIP) assay}

ChIP assays were performed with chromatin immunoprecipitation kit (Catalog No. 17-20000; Millipore, MA). Hippocampus tissue was exposed to $1 \%$ formaldehyde to crosslink with DNA proteins, ensuring DNA co-precipitation with the protein of interest. Glycine was then added to each sample tube to quench unreacted formaldehyde. Hippocampus tissue was broken open with an SDS Lysis Buffer containing Protease Inhibitor Cocktail II. Sonication was performed to shear the chromatin to a manageable size. Generally between 200 and 1000 bp of DNA is small enough to achieve a high degree of resolution during the detection step. The average fragment size is confirmed by gel electrophoresis. Protein G Agarose (Millipore, Billerica, MA) was added to each IP tube to remove proteins, or DNA, that might nonspecifically bind to the protein $\mathrm{G}$ agarose. Precleared chromatin was immunoprecipitated using an anti-acetyl histone $\mathrm{H} 3$ and H3K9 $\mathrm{Ab}$ (Millipore, Billerica, MA) or rabbit IgG as a control. It was then incubated overnight at $4{ }^{\circ} \mathrm{C}$ while being rotated. Protein G Agarose was added to each IP tube and incubated for $1 \mathrm{~h}$ at $4{ }^{\circ} \mathrm{C}$ with rotation in order to collect the antibody/antigen/DNA complex. After four sequential washes using four different wash buffers, the protein-DNA crosslinks were reversed during incubation at $65{ }^{\circ} \mathrm{C}$. DNA was purified to remove chromatin proteins and to prepare it for the detection step. The TLR4 gene corresponding to $5^{\prime}$ promoter regions $-627 /-437$ was amplified by PCR from the sheared DNA using the forward primer $5^{\prime}$-ACAAACAAACAAACCCACCA- $3^{\prime}$ and reverse primer $5^{\prime}$-TCCCACCTGTACTGCCTCTT-3'; GAPDH was amplified as a internal reference using the forward primer 5'-TACTAGCGGTTTTACGGGCG-3' and reverse primer $5^{\prime}$-TCGAACAGGAGGAGCAGAG AGCGA-3'. PCR conditions were as follows: for TLR4, Denaturation: $95{ }^{\circ} \mathrm{C}, 45 \mathrm{~s}$; Annealing: $58^{\circ} \mathrm{C}, 45 \mathrm{~s}$; Extension: $72{ }^{\circ} \mathrm{C}, 1 \mathrm{~min}$; 35 cycles; for GAPDH, Denaturation: $95{ }^{\circ} \mathrm{C}, 30 \mathrm{~s}$; Annealing: $55{ }^{\circ} \mathrm{C}, 45 \mathrm{~s}$; Extension: $72{ }^{\circ} \mathrm{C}$, $1 \mathrm{~min} ; 30$ cycles. PCR products were separated on $2 \%$ agarose gel. Band density was measured using G: BOX Chemi XR5 Imaging System (Syngene, UK).

\section{Statistical analysis}

All data are presented as the mean \pm SD. Differences among the means were analyzed by two-tailed Student $t$ test or ANOVA followed by the Bonferroni's post hoc test. $\mathrm{P}<0.05$ was considered statistically significant.

\section{Results}

SAHA attenuates KA-induced seizures

KA induced seizure in $84 \%$ of rats that did not receive SAHA, with $9 \%$ mortality. Latency and seizure scores were $64.83 \pm 13.99 \mathrm{~min}$ and $4.23 \pm 0.94$, respectively 
(Fig. 1). Different seizure scores were observed in SAHA-treated rats (Table 2). The mean latency and seizure score for "KA $+10 \mathrm{mg} / \mathrm{kg}$ SAHA" group was $75.11 \pm 14.27 \mathrm{~min}$ and $3.44 \pm 1.56$, and statistically different from the seizure control group $(\mathrm{P}<0.01$ and $\mathrm{P}<0.05$; Fig. 1; Table 2). The mean latency and seizure score for "KA + $50 \mathrm{mg} / \mathrm{kg}$ SAHA" group was $103.68 \pm 14.99 \mathrm{~min}$ and $2.37 \pm 1.48$, and statistically different from the seizure control group $(\mathrm{P}<0.001$; Fig. 1 ; Table 2). Further comparison showed that the above two data in "KA + $50 \mathrm{mg} / \mathrm{kg}$ SAHA" group were significantly different from "KA $+10 \mathrm{mg} / \mathrm{kg}$ SAHA" group $(\mathrm{P}<0.01$ and $\mathrm{P}<0.001$; Fig. 1 and Table 2). SAHA (10 or $50 \mathrm{mg} /$ $\mathrm{kg}$, i.p.) administration $30 \mathrm{~min}$ before KA administration increased the seizure latency and decreased the seizure score.

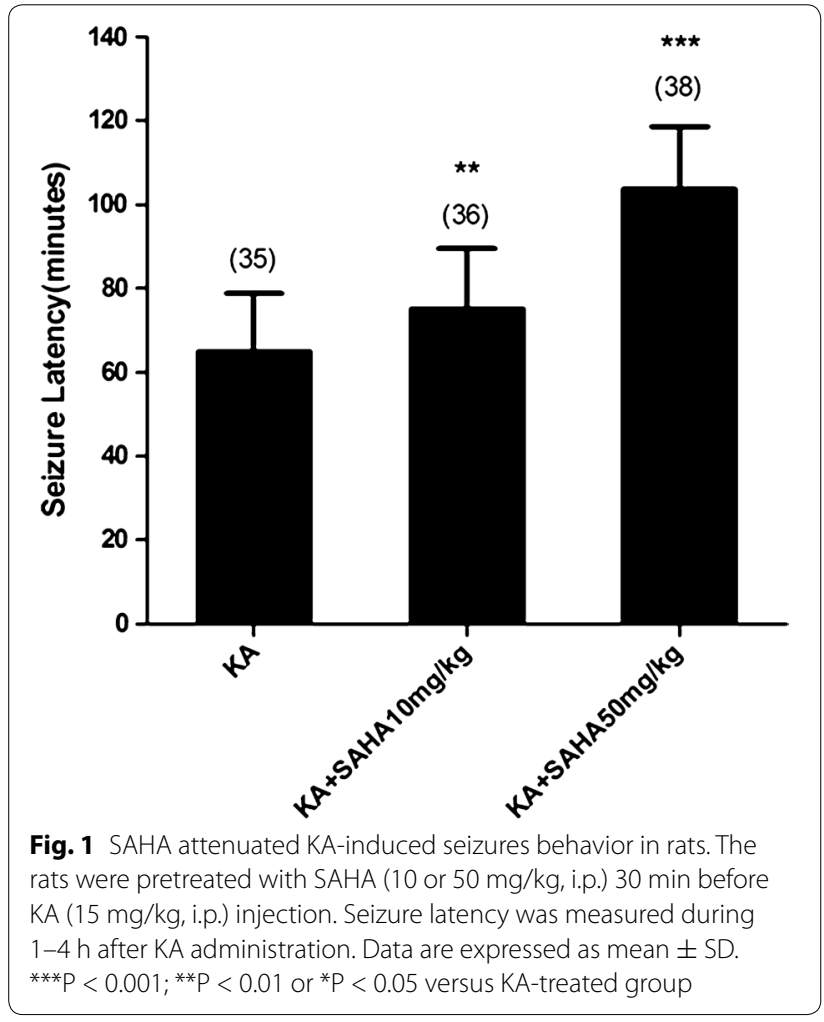

\section{SAHA reduces KA-induced neuronal cell death}

TUNEL staining showed considerable neuronal apoptosis at hippocampal CA1 in the KA-injected rats (Fig. 2b). SAHA pretreatment (10 or $50 \mathrm{mg} / \mathrm{kg}$ ) significantly attenuated KA-induced neuronal apoptosis (Fig. 2c, d). Figure $2 \mathrm{a}$ was the negative control group. In rats pretreated with SAHA $50 \mathrm{mg} / \mathrm{kg}$, the number of TUNEL positive cells at CA1 decreased significantly in comparison to SAHA $10 \mathrm{mg} / \mathrm{kg}$.

\section{SAHA suppresses KA-induced microglia activation}

To examine whether SAHA affected inflammatory processes in KA-injected rats, we analyzed microglia activation by detecting the expression of CD68, a marker of activated microglia. CD68 positive cells and intensity increased in KA-treated rats, but this increase was suppressed by SAHA pretreatment (Fig. 3c, d). In the saline and SAHA (50 mg/ $\mathrm{kg}$ )-treated rats, CD68 positive cells were sparse and CA1-region microglia showed a resting morphology with small cell bodies and long, thin, processes (Fig. 3a). KA-injected rats had a notable increase in the number of activated microglia in the CA1 region. These cells displayed enlarged amoeboid morphology and fewer and shorter processes, which indicated the activation state (Fig. 3b). SAHA-pretreatment significantly suppressed KA-induced microglia activation (Fig. 3c, d).

\section{SAHA reduces mRNA and protein levels of TLR4, MYD88, NF-KB P65 and IL-1 $\beta$}

To investigate the effect of SAHA on TLR4/MYD88 signaling, Real-time qPCR and Western blot were used to measure gene expression and protein levels of TLR4, MYD88, NF-kB P65 and IL-1 $\beta$. KA stimulation increased TLR4, MYD88, NF-кB P65 and IL-1 $\beta$ protein levels at $2 \mathrm{~h}, 6 \mathrm{~h}, 1 \mathrm{~d}$ and $2 \mathrm{~d}$ after KA injection in hippocampus CA1 region. SAHA $50 \mathrm{mg} / \mathrm{kg}$ significantly attenuated the increases (Fig. 4). Further gene expression analyses by Real-time qPCR confirmed that TLR4, MYD88, NF- $\mathrm{BB}$ P65, and IL-1 $\beta$ mRNA levels were consistent with protein level tendencies (Fig. 5). These results suggested that SAHA could suppress seizures-induced TLR4/MYD88 signaling.

Table 2 Rat seizure score

\begin{tabular}{|c|c|c|c|c|c|c|c|}
\hline & No seizure & Stage 1 & Stage 2 & Stage 3 & Stage 4 & Stage 5 & Mean score \\
\hline KA & 0 & 0 & 3 & 3 & 12 & 17 & $4.23 \pm 0.94$ \\
\hline $\mathrm{KA}+\mathrm{SAHA} 10 \mathrm{mg} / \mathrm{kg}$ & 3 & 1 & 6 & 4 & 11 & 11 & $3.44 \pm 1.56^{*}$ \\
\hline $\mathrm{KA}+\mathrm{SAHA} 50 \mathrm{mg} / \mathrm{kg}$ & 6 & 4 & 9 & 11 & 5 & 3 & $2.37 \pm 1.48^{* * *}$ \\
\hline
\end{tabular}

The rats in different seizures stage were counted and mean seizure score was analyzed by statistical method. Data are expressed as mean values \pm SD

${ }^{*} \mathrm{P}<0.05$; ${ }^{* * *} \mathrm{P}<0.001$, as compared with the KA-treated group 

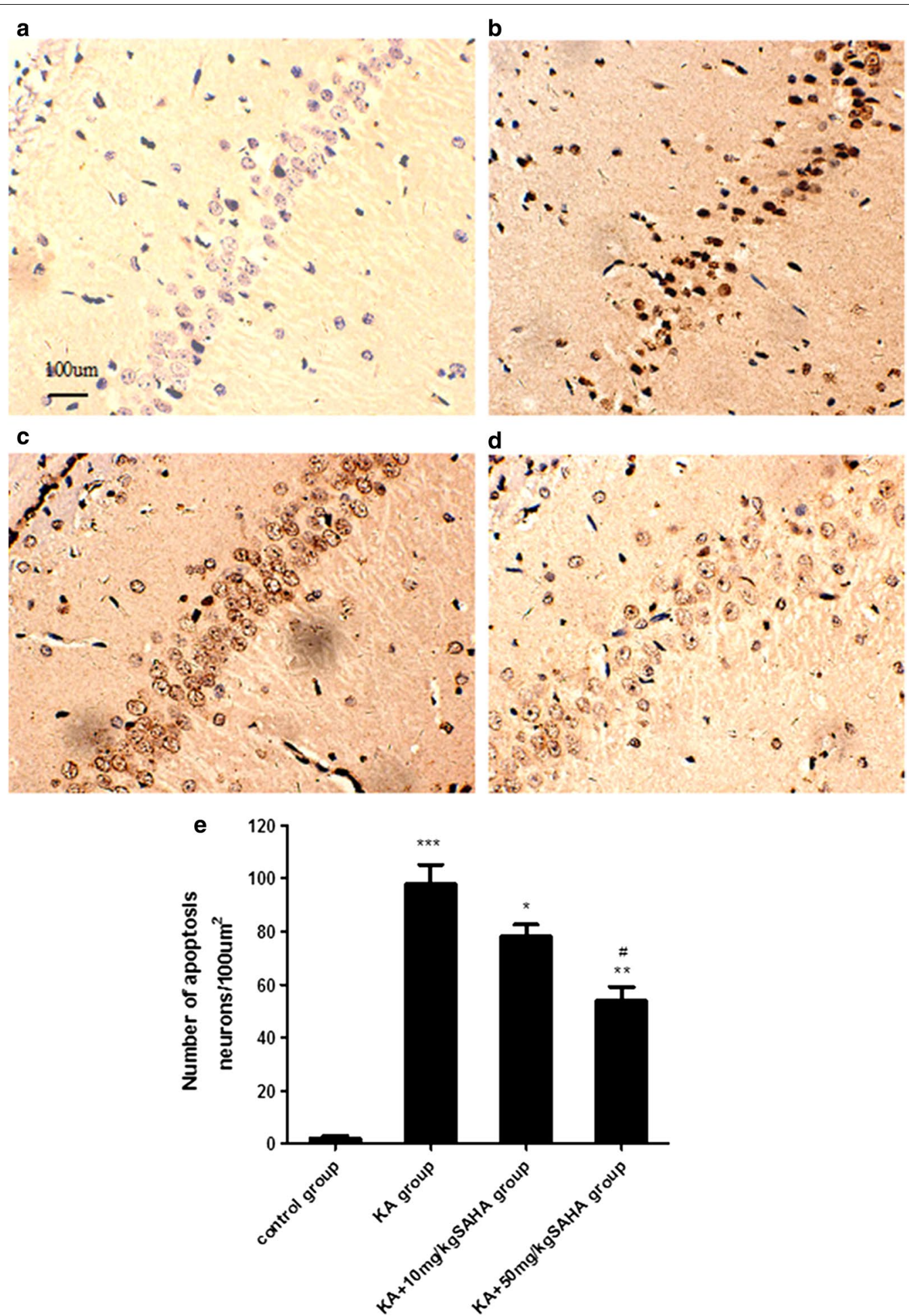

Fig. 2 SAHA attenuated KA-induced neuronal death in hippocampal CA1 region. SAHA (10 or 50 mg/kg) was administrated intraperitoneally 30 min before KA injection. Neuronal apoptosis were evaluated 3 days after KA injection. (a-d) TUNEL staining of hippocampal CA1 pyramidal neurons; a control group, b KA group, c KA + $10 \mathrm{mg} / \mathrm{kg}$ SAHA group, d KA +50 mg/kg SAHA group, e TUNEL positive cells quantities for each group. Data are expressed as mean \pm SD. Scale bar $=100 \mu \mathrm{m}$. ${ }^{*} \mathrm{P}<0.05$, KA group versus $\mathrm{KA}+10 \mathrm{mg} / \mathrm{kg}$ SAHA group; ${ }^{* *} \mathrm{P}<0.01$, KA group versus $\mathrm{KA}+50 \mathrm{mg} / \mathrm{kg}$ SAHA group; ${ }^{* * \mathrm{P}}<0.001, \mathrm{KA}$ group versus control group; ${ }^{\# \mathrm{P}}<0.001, \mathrm{KA}+10 \mathrm{mg} / \mathrm{kgSAHA}$ group versus $\mathrm{KA}+50 \mathrm{mg} / \mathrm{kg} \mathrm{SAHA}$ group 

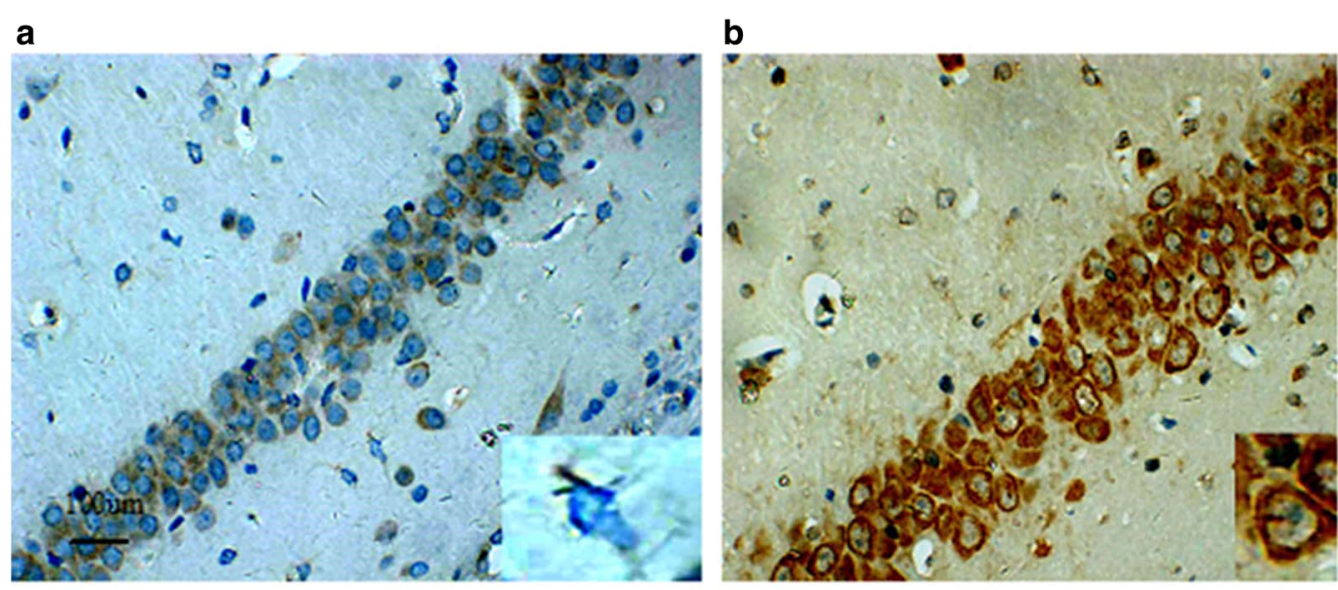

C

\section{d}
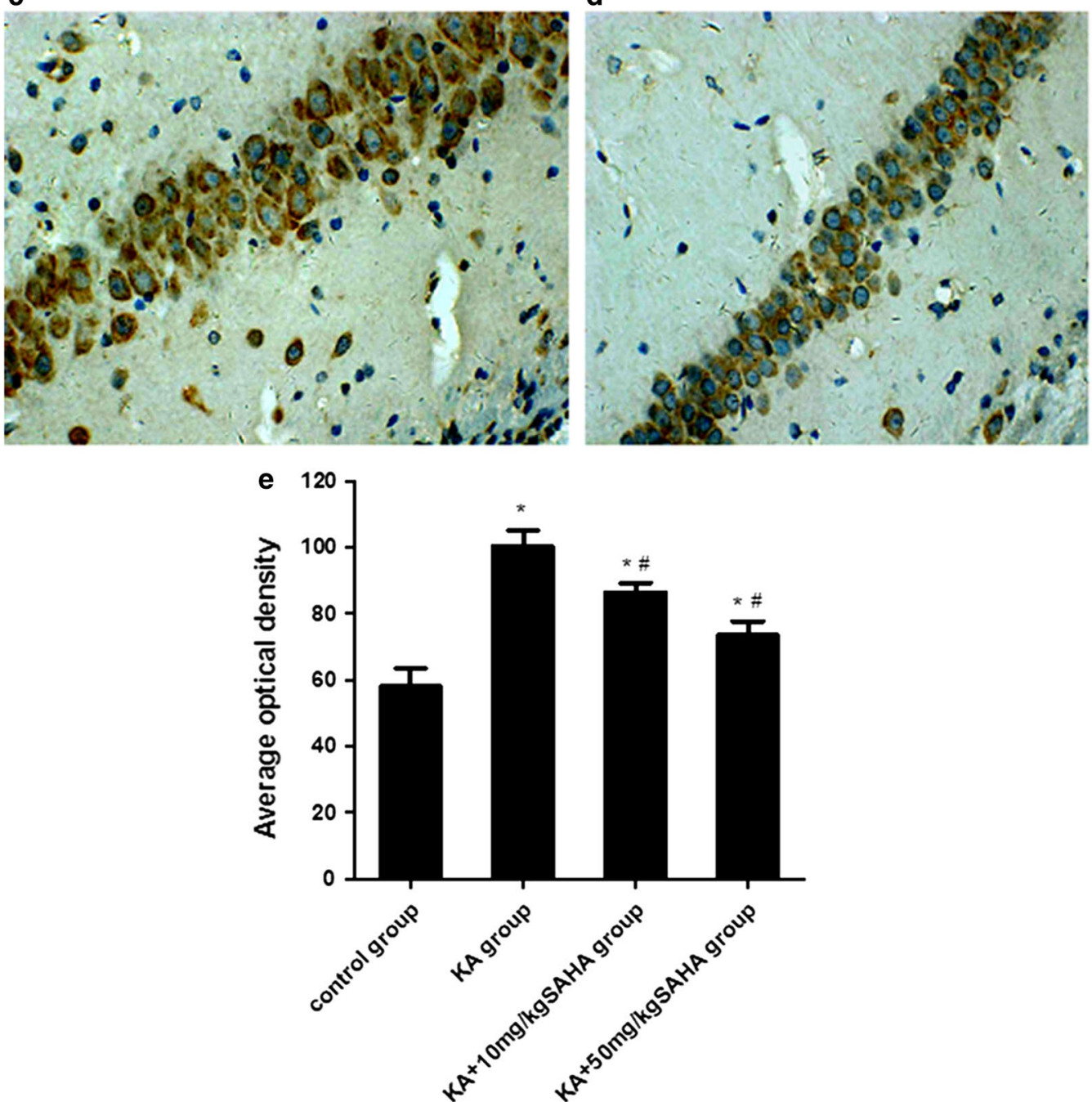

Fig. 3 SAHA attenuated KA-induced microglia activation in the hippocampal CA1 region. SAHA (10 or $50 \mathrm{mg} / \mathrm{kg}$ ) was administrated intraperitoneally 30 min before KA injection, and the hippocampal sections were stained with anti-CD68 antibody 3 days after KA injection. (a-d) CD68 immunostaining of activated microglia in hippocampal CA1 region; a control group; b KA group; $\mathbf{c} K A+10 \mathrm{mg} / \mathrm{kg} \mathrm{SAHA} \mathrm{group;} \mathrm{d} \mathrm{KA} \mathrm{+} 50 \mathrm{mg} / \mathrm{kg} \mathrm{SAHA;}$ e Average optical density of CD68 immunoreactive cells in each group. Insets in $\mathbf{a}$ and $\mathbf{b}$ show morphological change after KA administration under higher magnification. Data are expressed as mean \pm SD, Scale bar $=100 \mu \mathrm{m}$ for $\mathbf{a}-\mathbf{d}$. ${ }^{*} P<0.01$ versus control group; $P<0.01$ versus KA group 


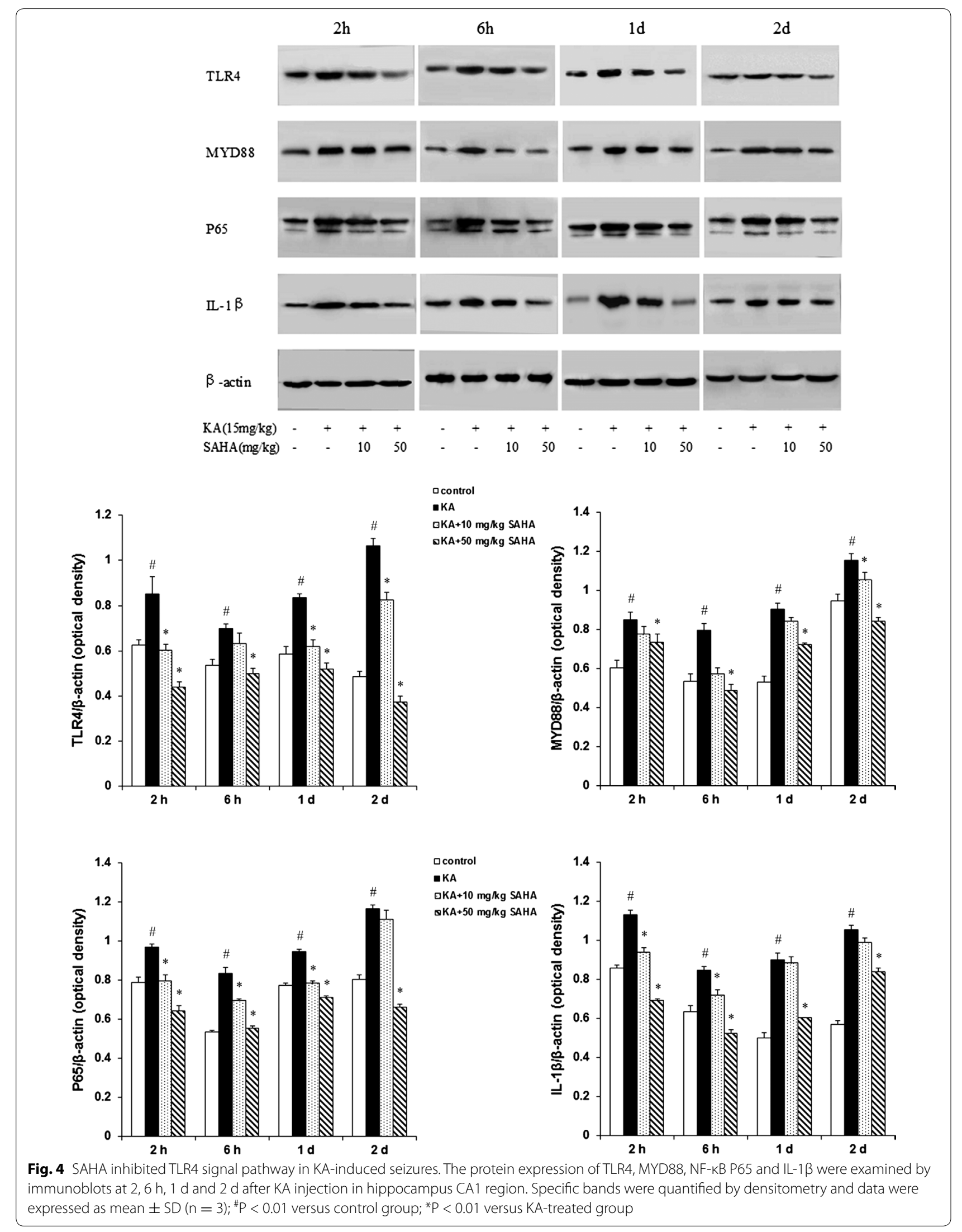



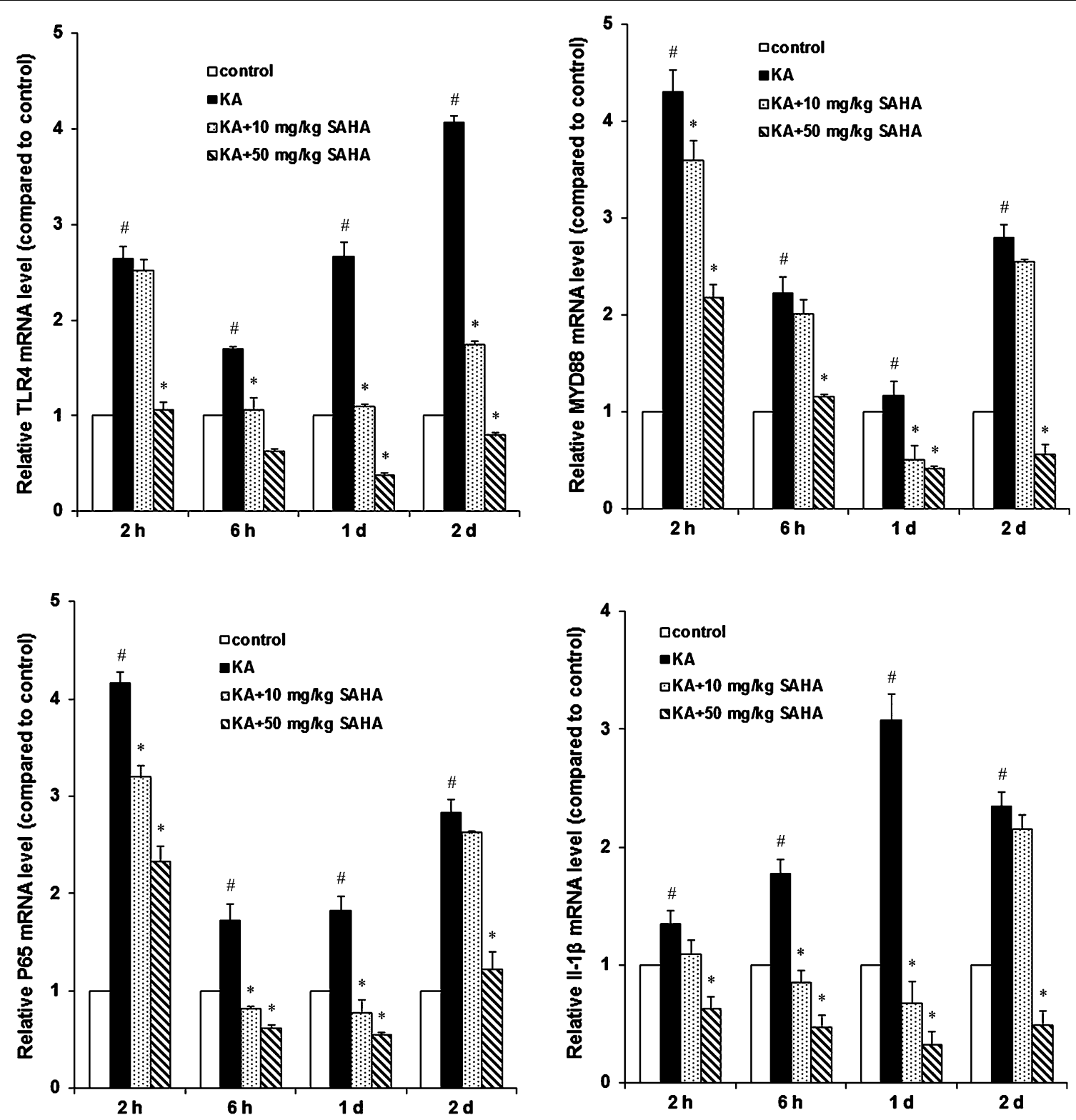

Fig. 5 SAHA attenuated KA-induced mRNA expression of TLR4, MYD88, NF-KB and IL-1 $\beta$ in hippocampus. In hippocampus CA1 region, mRNA expression of TLR4, MYD88, NF-KB and IL-1 $\beta$ were measured with real-time Quantitative PCR at 2, $6 \mathrm{~h}, 1 \mathrm{~d}$ and $2 \mathrm{~d}$ after KA injection. Relative quantification data were expressed as mean $\pm S D(n=3)$. ${ }^{*} P<0.01$ versus control group; ${ }^{*} P<0.01$ versus KA-treated group

SAHA inhibits TLR4 gene transcription by histone acetylation regulation

Twenty-four hours after KA-induced seizures, histone acetylation on the TLR4 gene $5^{\prime}$ region was analyzed by ChIP assays using anti-acetyl histone $\mathrm{H} 3$, and $\mathrm{H} 3 \mathrm{~K} 9$ antibodies. As shown in Fig. 6, H3 histone acetylation levels significantly decreased while H3K9 significantly increased in the KA treatment group when compared to the control group. $\mathrm{H} 3$ and $\mathrm{H} 3 \mathrm{~K} 9$ acetylation level returned to control levels after SAHA $50 \mathrm{mg} / \mathrm{kg}$ pretreatment (Fig. 6a-d). The mRNA expression of TLR4 increased significantly with KA treatment, which was reversed by SAHA (Fig. 5a). The results suggested that the expression of TLR4 was dependent on the acetylation levels of H3K9; SAHA led to hypoacetylation of $\mathrm{H} 3 \mathrm{~K} 9$, which in turn resulted in downregulation of the expression of TLR4. 


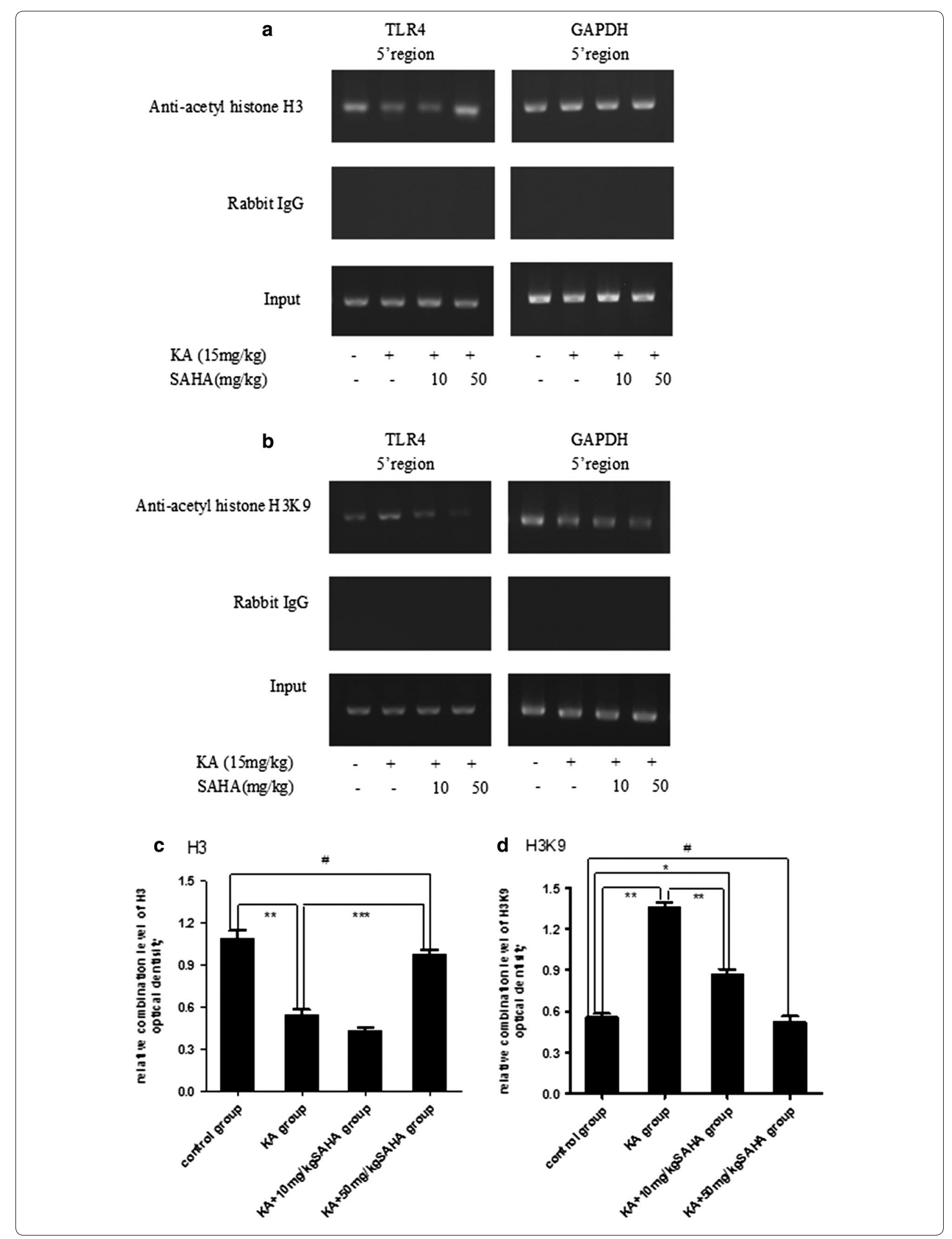


(See figure on previous page.)

Fig. 6 SAHA inhibited TLR4 gene transcription by histone acetylation regulation. Histones interaction with the $5^{\prime}$ region of the TLR4 gene were examined with ChIP assays using anti-acetyl histone $\mathbf{a} \mathrm{H3}$ and $\mathbf{b} \mathrm{H} 3 \mathrm{~K} 9$ antibodies. Rabbit lgG was used as a negative control. The "input" lanes represent the results of PCR using non-immunoprecipitated chromatin as templates. The $5^{\prime}$ regions of the TLR4 gene, with the $5^{\prime}$ regions of the GAPDH gene as an internal reference, were amplified by PCR from the immunoprecipitated chromatin. The DNA bands for $\mathbf{c} \mathrm{H} 3$ and $\mathbf{d} \mathrm{H} 3 \mathrm{~K} 9$ were quantified by densitometry and data expressed as mean $\pm S D(n=3)$. Bars expressed as the ratio of optical density (OD) of the samples to the corresponding internal standard (GAPDH). ${ }^{*} P<0.05 ;{ }^{* *} P<0.01 ;{ }^{* *} \mathrm{P}<0.001 ;{ }^{*} \mathrm{P}>0.05$

\section{Discussion}

To date, the understanding of potential protective mechanisms and pathogenesis of seizures-induced brain injury is still very limited [33-35]. We hypothesized that SAHA would have an anticonvulsant effect. This study shows that SAHA has an anticonvulsant effect in a KA seizure model in rats. We chose this model because KA-induced seizure activity and brain damage are similar to those in humans [17, 36, 37] and are associated with excessive glutamate release [38-40]. In agreement with previous studies, KA injection (15 mg/kg, i.p.) induced epileptic seizures in this study [36, 41-43]. SAHA pretreatment (10 or $50 \mathrm{mg} / \mathrm{kg}$ ) reduced KA-induced neuronal apoptosis, suggesting SAHA as a potent neuroprotective and anticonvulsant agent.

Previous studies suggest that KA-induced microglia activation can cause hippocampal neuron apoptosis [44-46]. Therefore, preventing microglia activation protects hippocampus against neuron apoptosis caused by KA-induced seizures [47]. In this study, we noted that the number of activated microglia immunostained for CD68, a marker for microglia activation [48], was significantly higher in the hippocampus in KA-treated rats. SAHA pretreatment reduced the number of activated microglia. Thus, SAHA may have an anti-inflammatory function and neuroprotective effects. However, how SAHA affects microglia activation remains unclear. Microglia activation and subsequent production of pro-inflammatory cytokines are believed to contribute to neuronal damage $[49,50]$. Thus, there might be a direct interaction between SAHA and these factors; this needs to be explored in future studies.

A previous study reported that a functional TLR4/ MyD88 cascade in microglia was essential for neuronal injury [51-55]. In this study, our findings indicate that SAHA attenuated the inflammatory mediators production by inhibiting the TLR4/MyD88 signaling pathway associated with activated microglia. Thus, the anti-neuroinflammation effect of SAHA on activated microglia may contribute to the treatment of conditions relating to inflammatory response.

In this study, ChIP experiments indicated that KA increased histone $\mathrm{H} 3$ acetylated at lysine 9 (H3K9) of TLR4 gene and SAHA pretreatment reversed the increase. Lysine acetylation is a common post-translational modification on both histones and non-histones; hyperacetylation of lysine is conventionally associated with enhanced gene expression [56]. This means that TLR4 gene transcription is epigenetically suppressed by adding SAHA in KA-induced seizures, as found in this study. In agreement with previous studies showing that HDAC inhibitors increased gene expression and reversed the reduction of histone $\mathrm{H} 3$ acetylation levels in rat neuroinflammation and brain damage models $[57,58]$, we found in this study that SAHA suppressed H3K9 acetylation levels and then reduced TLR4 gene expression in the rat seizures model.

\section{Conclusions}

In summary, the study shows that SAHA can suppress seizure-induced microglia activation and neuron apoptosis, and inhibit TLR4 expression through histone acetylation regulation by inhibiting TLR4/MYD88 signaling. This strongly suggests a potential neuroprotective effect of SAHA against neuroinflammation-induced brain damage. These findings provide new insights into the treatment of epilepsy and other neurodegenerative disorders.

\section{Abbreviations}

ChIP: chromatin immunoprecipitation; HAT: histone acetyltransferase; HDAC: histone deacetylase; MyD88: myeloid differentiation primary response protein 88; PRR: pattern recognition receptor; TLR: toll-like-receptor.

\section{Authors' contributions}

QPH participated in study design, collected data, carried out data analysis, and drafted the manuscript. DAM participated in study design, carried out data analysis, and performed data check and proofreading. Both authors read and approved the final manuscript.

\section{Acknowledgements \\ We are grateful to Li-Qun Liu and Ling-Juan Liu for their excellent technical assistance and advice. This work was supported by department of Pediatrics, the Second Xiang-Ya Hospital, Central South University, China.}

\section{Ethics statement}

All animal care, breeding, and surgical procedures were approved by the Laboratory Animal Users Committee at the Second Xiangya Hospital, Central South University, Changsha, China.

Received: 28 December 2015 Accepted: 11 May 2016

Published online: 18 May 2016 


\section{References}

1. Chiu KM, Wu CC, Wang MJ, Lee MY, Wang SJ. Protective effects of bupivacaine against kainic acid-induced seizure and neuronal cell death in the rat hippocampus. Biol Pharm Bull. 2015;38:522-30.

2. Bernardino L, Ferreira R, Cristovao AJ, Sales F, Malva JO. Inflammation and neurogenesis in temporal lobe epilepsy. Curr Drug Targets CNS Neurol Disord. 2005:4:349-60.

3. Vezzani A, Granata T. Brain inflammation in epilepsy: experimental and clinical evidence. Epilepsia. 2005;46:1724-43.

4. Matin N, Tabatabaie O, Falsaperla R, Lubrano R, Pavone P, et al. Epilepsy and innate immune system: a possible immunogenic predisposition and related therapeutic implications. Hum Vaccin Immunother 2015;11:2021-9.

5. Xiao Z, Peng J, Yang L, Kong H, Yin F. Interleukin-1 beta plays a role in the pathogenesis of mesial temporal lobe epilepsy through the PI3KJAkt/ mTOR signaling pathway in hippocampal neurons. J Neuroimmunol. 2015;282:110-7.

6. Diamond ML, Ritter AC, Failla MD, Boles JA, Conley YP, et al. IL-1 beta associations with posttraumatic epilepsy development: a genetics and biomarker cohort study. Epilepsia. 2015;56:991-1001.

7. Vezzani A, Balosso S, Ravizza T. The role of cytokines in the pathophysiology of epilepsy. Brain Behav Immun. 2008;22:797-803.

8. Kreutzberg GW. Microglia: a sensor for pathological events in the CNS. Trends Neurosci. 1996;19:312-8.

9. Carpentier PA, Duncan DS, Miller SD. Glial toll-like receptor signaling in central nervous system infection and autoimmunity. Brain Behav Immun. 2008;22:140-7.

10. Rivieccio MA, Suh HS, Zhao Y, Zhao ML, Chin KC, et al. TLR3 ligation activates an antiviral response in human fetal astrocytes: a role for viperin/ cig5. J Immunol. 2006;177:4735-41.

11. Suh HS, Zhao ML, Rivieccio M, Choi S, Connolly E, et al. Astrocyte indoleamine 2,3-dioxygenase is induced by the TLR3 ligand poly(l:C): mechanism of induction and role in antiviral response. J Virol. 2007;81:9838-50.

12. Suh HS, Zhao ML, Choi N, Belbin TJ, Brosnan CF, et al. TLR3 and TLR4 are innate antiviral immune receptors in human microglia: role of IRF3 in modulating antiviral and inflammatory response in the CNS. Virology. 2009;392:246-59.

13. Akira S, Uematsu S, Takeuchi O. Pathogen recognition and innate immunity. Cell. 2006;124:783-801.

14. Suh HS, Brosnan CF, Lee SC. Toll-like receptors in CNS viral infections. Curr Top Microbiol Immunol. 2009;336:63-81.

15. Okun E, Griffioen KJ, Lathia JD, Tang SC, Mattson MP, et al. Toll-like receptors in neurodegeneration. Brain Res Rev. 2009;59:278-92.

16. Verstak B, Nagpal K, Bottomley SP, Golenbock DT, Hertzog PJ, et al. MyD88 adapter-like (Mal)/TIRAP interaction with TRAF6 is critical for TLR2- and TLR4-mediated NF-kappaB proinflammatory responses. J Biol Chem. 2009;284:24192-203.

17. Ben-Ari Y, Cossart R. Kainate, a double agent that generates seizures: two decades of progress. Trends Neurosci. 2000;23:580-7.

18. Choi DW. Excitotoxic cell death. J Neurobiol. 1992:23:1261-76.

19. Clarke VR, Collingridge GL, Lauri SE, Taira T. Synaptic kainate receptors in CA1 interneurons gate the threshold of theta-frequency-induced longterm potentiation. J Neurosci. 2012;32:18215-26.

20. Weiss S, Cataltepe O, Cole AJ. Anatomical studies of DNA fragmentation in rat brain after systemic kainate administration. Neuroscience. 1996:74:541-51.

21. Faraco G, Pancani T, Formentini L, Mascagni P, Fossati G, et al. Pharmacological inhibition of histone deacetylases by suberoylanilide hydroxamic acid specifically alters gene expression and reduces ischemic injury in the mouse brain. Mol Pharmacol. 2006;70:1876-84

22. Kim HJ, Rowe M, Ren M, Hong JS, Chen PS, et al. Histone deacetylase inhibitors exhibit anti-inflammatory and neuroprotective effects in a rat permanent ischemic model of stroke: multiple mechanisms of action. J Pharmacol Exp Ther. 2007;321:892-901.

23. Ren $M$, Leng $Y$, Jeong $M$, Leeds $P R$, Chuang DM. Valproic acid reduces brain damage induced by transient focal cerebral ischemia in rats: potential roles of histone deacetylase inhibition and heat shock protein induction. J Neurochem. 2004;89:1358-67.

24. Camelo S, Iglesias AH, Hwang D, Due B, Ryu H, et al. Transcriptional therapy with the histone deacetylase inhibitor trichostatin $A$ ameliorates experimental autoimmune encephalomyelitis. J Neuroimmunol. 2005;164:10-21.

25. Ferrante RJ, Kubilus JK, Lee J, Ryu H, Beesen A, et al. Histone deacetylase inhibition by sodium butyrate chemotherapy ameliorates the neurodegenerative phenotype in Huntington's disease mice. J Neurosci. 2003;23:9418-27

26. Gardian G, Browne SE, Choi DK, Klivenyi P, Gregorio J, et al. Neuroprotective effects of phenylbutyrate in the N171-82Q transgenic mouse model of Huntington's disease. J Biol Chem. 2005;280:556-63.

27. Butler KV, Kozikowski AP. Chemical origins of isoform selectivity in histone deacetylase inhibitors. Curr Pharm Des. 2008;14:505-28.

28. Kozikowski AP, Chen Y, Gaysin A, Chen B, D'Annibale MA, et al. Functional differences in epigenetic modulators-superiority of mercaptoacetamide-based histone deacetylase inhibitors relative to hydroxamates in cortical neuron neuroprotection studies. J Med Chem. 2007:50:3054-61.

29. O'Neill LA, Bowie AG. The family of five: TIR-domain-containing adaptors in Toll-like receptor signalling. Nat Rev Immunol. 2007;7:353-64.

30. Wang X, Stridh L, Li W, Dean J, Elmgren A, et al. Lipopolysaccharide sensitizes neonatal hypoxic-ischemic brain injury in a MyD88-dependent manner. J Immunol. 2009;183:7471-7.

31. Racine RJ. Modification of seizure activity by electrical stimulation. II. Motor seizure. Electroencephalogr Clin Neurophysiol. 1972;32:281-94

32. Chiu TL, Wang MJ, Su CC. The treatment of glioblastoma multiforme through activation of microglia and TRAIL induced by rAAV2-mediated IL-12 in a syngeneic rat model. J Biomed Sci. 2012;19:45.

33. Carlson H, Ronne-Engstrom E, Ungerstedt U, Hillered L. Seizure related elevations of extracellular amino acids in human focal epilepsy. Neurosci Lett. 1992;140:30-2

34. Chapman AG, Elwes RD, Millan MH, Polkey CE, Meldrum BS. Role of glutamate and aspartate in epileptogenesis; contribution of microdialysis studies in animal and man. Epilepsy Res Suppl. 1996:12:239-46.

35. Meldrum BS. The role of glutamate in epilepsy and other CNS disorders. Neurology. 1994;44:S14-23.

36. Friedman LK, Pellegrini-Giampietro DE, Sperber EF, Bennett MV, Moshe $S L$, et al. Kainate-induced status epilepticus alters glutamate and GABAA receptor gene expression in adult rat hippocampus: an in situ hybridization study. J Neurosci. 1994;14:2697-707.

37. Park HJ, Kim HJ, Park HJ, Ra J, Zheng LT, et al. Protective effect of topiramate on kainic acid-induced cell death in mice hippocampus. Epilepsia. 2008;49:163-7.

38. Chittajallu R, Vignes M, Dev KK, Barnes JM, Collingridge GL, et al. Regulation of glutamate release by presynaptic kainate receptors in the hippocampus. Nature. 1996;379:78-81.

39. Ferkany JW, Zaczek R, Coyle JT. Kainic acid stimulates excitatory amino acid neurotransmitter release at presynaptic receptors. Nature. 1982:298:757-9.

40. Sperk G. Kainic acid seizures in the rat. Prog Neurobiol. 1994:42:1-32.

41. Spigolon G, Veronesi C, Bonny C, Vercelli A. C-Jun N-terminal kinase signaling pathway in excitotoxic cell death following kainic acid-induced status epilepticus. Eur J Neurosci. 2010;31:1261-72.

42. Ben-Ari Y. Limbic seizure and brain damage produced by kainic acid: mechanisms and relevance to human temporal lobe epilepsy. Neuroscience $1985: 14: 375-403$.

43. Wang FX, Liu SY, Zheng X, Chen X, Lu LX, et al. TLR1 expression in mouse brain was increased in a KA-induced seizure model. Inflamm Res. 2015;64:487-95.

44. Nabeka H, Shimokawa T, Doihara T, Saito S, Wakisaka H, et al. A prosaposin-derived peptide alleviates kainic acid-induced brain injury. PLOS ONE. 2015;10:e0126856.

45. Avignone E, Ulmann L, Levavasseur F, Rassendren F, Audinat E. Status epilepticus induces a particular microglial activation state characterized by enhanced purinergic signaling. J Neurosci. 2008;28:9133-44.

46. Kim DH, Yoon BH, Jung WY, Kim JM, Park SJ, et al. Sinapic acid attenuates kainic acid-induced hippocampal neuronal damage in mice. Neuropharmacology. 2010;59:20-30

47. Penkowa M, Florit S, Giralt M, Quintana A, Molinero A, et al. Metallothionein reduces central nervous system inflammation, neurodegeneration, and cell death following kainic acid-induced epileptic seizures. J Neurosci Res. 2005;79:522-34. 
48. Larochelle A, Bellavance MA, Rivest S. Role of adaptor protein MyD88 in TLR-mediated preconditioning and neuroprotection after acute excitotoxicity. Brain Behav Immun. 2015;46:221-31.

49. Klegeris A, Choi HB, McLarnon JG, McGeer PL. Functional ryanodine receptors are expressed by human microglia and THP-1 cells: their possible involvement in modulation of neurotoxicity. J Neurosci Res. 2007:85:2207-15.

50. Klegeris A, McGeer EG, McGeer PL. Therapeutic approaches to inflammation in neurodegenerative disease. Curr Opin Neurol. 2007;20:351-7.

51. Wang D, Shi J, Lv S, Xu W, Li J, et al. Artesunate attenuates lipopolysaccharide-stimulated proinflammatory responses by suppressing TLR4, MyD88 expression, and NF-kappaB activation in microglial cells. Inflammation. 2015;38:1925-32.

52. Lehnardt S, Lachance $C$, Patrizi S, Lefebvre S, Follett PL, et al. The toll-like receptor TLR4 is necessary for lipopolysaccharide-induced oligodendrocyte injury in the CNS. J Neurosci. 2002;22:2478-86.

53. Olson JK, Miller SD. Microglia initiate central nervous system innate and adaptive immune responses through multiple TLRs. J Immunol. 2004;173:3916-24.
54. Yao L, Kan EM, Lu J, Hao A, Dheen ST, et al. Toll-like receptor 4 mediates microglial activation and production of inflammatory mediators in neonatal rat brain following hypoxia: role of TLR4 in hypoxic microglia. J Neuroinflammation. 2013;10:23.

55. Zhang G, Ghosh S. Toll-like receptor-mediated NF-kappaB activation: a phylogenetically conserved paradigm in innate immunity. J Clin Invest. 2001;107:13-9.

56. Strahl BD, Allis CD. The language of covalent histone modifications. Nature. 2000;403:41-5.

57. Soliman ML, Smith MD, Houdek HM, Rosenberger TA. Acetate supplementation modulates brain histone acetylation and decreases interleukin-1 beta expression in a rat model of neuroinflammation. J Neuroinflammation. 2012;9:51.

58. Zhang B, West EJ, Van KC, Gurkoff GG, Zhou J, et al. HDAC inhibitor increases histone $\mathrm{H} 3$ acetylation and reduces microglia inflammatory response following traumatic brain injury in rats. Brain Res. 2008;1226:181-91.

\section{Submit your next manuscript to BioMed Central and we will help you at every step:}

- We accept pre-submission inquiries

- Our selector tool helps you to find the most relevant journal

- We provide round the clock customer support

- Convenient online submission

- Thorough peer review

- Inclusion in PubMed and all major indexing services

- Maximum visibility for your research

Submit your manuscript at www.biomedcentral.com/submit 